\title{
Current understandings in treating children with steroid-resistant nephrotic syndrome
}

\author{
Jiwon M. Lee ${ }^{1} \cdot$ Andreas Kronbichler ${ }^{2} \cdot$ Jae II Shin ${ }^{3,4,5} \cdot{\text { Jun } \mathrm{Oh}^{6}}^{6}$ \\ Received: 7 April 2019 / Revised: 22 December 2019 / Accepted: 7 January 2020 / Published online: 21 February 2020 \\ (C) The Author(s) 2020
}

\begin{abstract}
Steroid-resistant nephrotic syndrome (SRNS) remains a challenge for paediatric nephrologists. SRNS is viewed as a heterogeneous disease entity including immune-based and monogenic aetiologies. Because SRNS is rare, treatment strategies are individualized and vary among centres of expertise. Calcineurin inhibitors (CNI) have been effectively used to induce remission in patients with immune-based SRNS; however, there is still no consensus on treating children who become either CNI-dependent or CNI-resistant. Rituximab is a steroid-sparing agent for patients with steroid-sensitive nephrotic syndrome, but its efficacy in SRNS is controversial. Recently, several novel monoclonal antibodies are emerging as treatment option, but their efficacy remains to be seen. Non-immune therapies, such as angiotensin-converting enzyme inhibitors or angiotensin II receptor blockers, have been proven efficacious in children with SRNS and are recommended as adjuvant agents. This review summarizes and discusses our current understandings in treating children with idiopathic SRNS.
\end{abstract}

Keywords Nephrotic syndrome $\cdot$ Resistant $\cdot$ Intractable $\cdot$ Monogenic $\cdot$ Treatment $\cdot$ Children

\section{Introduction}

Nephrotic syndrome is the most common glomerular disease in childhood. The prevalence is $12-16$ per 100,000 children aged under 16 [1]. The reported annual incidence in children

Jae Il Shin and Jun Oh contributed equally to this work.

Jun Oh

j.oh@uke.de

Jae Il Shin

shinji@yuhs.ac

1 Department of Pediatrics, Chungnam National University Hospital, Daejeon, South Korea

2 Department of Internal Medicine IV (Nephrology and Hypertension), Medical University Innsbruck, Innsbruck, Austria

3 Department of Pediatrics, Yonsei University College of Medicine, 50 Yonsei-ro, Seodaemun-gu, C.P.O. Box 8044, Seoul 120-752, South Korea

4 Division of Pediatric Nephrology, Severance Children's Hospital, Seoul, South Korea

5 Institute of Kidney Disease Research, Yonsei University College of Medicine, Seoul, South Korea

6 Department of Pediatrics Nephrology, University Hamburg-Eppendorf, Martinistrasse, 5220246 Hamburg, Germany varies between 1.2 and 3.5 per 100,000 per year in Western Europe [2-4], 4.7 per 100,000 per year worldwide [5] and up to 6.5 per 100,000 per year in Japan [6]. Although more than $85 \%$ of children with nephrotic syndrome respond to corticosteroids, approximately $10-15 \%$ remain unresponsive or later become steroid-resistant [7-11]. Steroid-resistant nephrotic syndrome (SRNS) has been associated with unfavourable renal prognosis, with $36-50 \%$ of patients progressing to endstage kidney disease within 10 years [12-14].

Standardized management of SRNS has been hampered by the paucity of high-quality trial evidence. SRNS is rare, and as such treatment options are based on anecdotes, case reports mainly illustrating individual centre practice and studies with relatively small numbers of patients. Protocols are therefore generally individualized using a broad framework. In addition, there are few clinical studies with a sufficient power in children with SRNS.

\section{Recent perspectives on the stratification of nephrotic syndrome}

For many years, idiopathic nephrotic syndrome has been classified based on the patient's response to steroids: as steroidsensitive or steroid-resistant. SRNS, most commonly focal segmental glomerulosclerosis (FSGS) in histology, has long 
been thought as an immune-mediated disease, either with or without circulating factors. However, recent techniques have enabled the discovery of a multitude of genetic mutations that cause nephrotic syndrome. Because this genetic disease group is not immune-mediated, it is theoretically unresponsive to steroids or other immunosuppressants and thus is classified as SRNS. Monogenic, non-immune-mediated causes reportedly account for up to one third of SRNS cases overall, and to date more than 60 genes related to SRNS have been described $[15,16]$. Therefore, SRNS is now a rather heterogeneous constellation of distinct aetiologies. As to this, a recent comprehensive review by Saleem [15] has proposed a novel molecular stratification of SRNS based on disease mechanisms as monogenic, immune-mediated with circulating factors and immune-mediated without circulating factors.

This review attempts to appreciate the newly proposed stratification by summarizing the treatment of monogenic SRNS in a separate section; however such efforts are limited because most publications have not (or could not at the time) stratified patients by their genetic bases. Nevertheless, this review attempts to summarize current understandings and controversies in therapies available for children with idiopathic (primary) SRNS.

\section{Intensified immunosuppression and adjuvant agents for SRNS}

\section{Intravenous methylprednisolone pulse}

The mechanism of action of steroid therapy in inducing remission is complex. Its main actions are immune modulation by binding to specific cytoplasmic receptors, modifying transcription and protein synthesis and thereby suppressing inflammatory reactions and humoral immune response [17, 18]. The rationale for administration of intravenous methylprednisolone pulse despite initial steroid unresponsiveness is based on the results from observational studies which reported remission in steroid- and/or cyclosporine-resistant nephrotic syndrome. Previous studies reported remission induced in SRNS using methylprednisolone pulses with concomitant immunosuppressants [19-21] and by methylprednisolone alone $[22,23]$. Specifically, Mori et al. reported remission after methylprednisolone pulse therapy in 78\% (7/9) of patients who were resistant to steroids and cyclophosphamide (CPM) and/or cyclosporine A (CSA) [23]. The studies showed that prolonged methylprednisolone pulses with alternate-day oral steroids may be efficacious, even when patients are considered to have steroid- and multidrug-resistant nephrotic syndrome. Mechanisms leading to such a late remission following steroid pulses despite initial resistance need to be elucidated [12].

However, several studies argue against the use of prolonged high-dose steroids in SRNS [9, 24, 25], given the adverse effects of long-term steroid use. In addition, in the PodoNet registry, a large web-based clinical database in Europe for idiopathic SRNS including congenital nephrotic syndrome and high-dose steroids (including pulses) used as first-line therapy were not efficacious in $\sim 85 \%$ [9]. Still, if there was a partial remission seen with conventional oral prednisolone therapy, it appears to be worth trying intravenous methylprednisolone pulses as combination therapy.

\section{Calcineurin inhibitors}

There are two mechanisms of the antiproteinuric effect exerted by calcineurin inhibitors (CNI) discussed (1) through inhibition of T-cell signalling in lymphocytes and (2) direct nonimmune effects on the podocyte actin cytoskeleton [7, 26]. The latter part of the mechanism explains the partial efficacy of CNIs in non-immune-mediated, monogenic SRNS, reported in the literature [27]. Complete or partial remission rates in SRNS with the use of CNIs have been in the range of 30-80\% in observational studies [11] and randomized controlled trials (RCTs) [28, 29].

A multicentre RCT [29] showed that CNIs significantly increased the proportion of children with SRNS obtaining remission, compared with intravenous CPM. This finding was supported by a systematic review of RCTs by Hodson et al., which showed that CSA was effective irrespective of renal pathology compared with placebo and intravenous CPM [30].

Combination of steroids and CNIs has been proven efficacious for treating SRNS in systematic reviews $[28,30]$ and is currently recommended by the Kidney Disease Improving Global Outcomes (KDIGO) guideline [12]. The guideline recommends continuation of CNI in SRNS for a minimum of 12 months [31]. This statement was supported by a study highlighting the benefits of continued treatment with tacrolimus (TAC) for 18 months [32]. There is, however, no international consensus on duration of treatment or optimal target trough levels.

While other CNIs like voclosporin are currently being tested in clinical trials, CSA and TAC are the two major agents which are commonly used in the treatment of nephrotic syndrome. TAC and CSA are generally accepted to have similar therapeutic effects [7], showing similarly superior efficacy over CPM [29] and no significant difference in the numbers of SRNS patients achieving remission [30, 33]. Prasad et al. studied 45 children with SRNS who were resistant to CPM, in which they treated the patients with either CSA or TAC and compared treatment outcome at 6 months [33]. They showed that CNIs were effective in CPM-resistant nephrotic syndrome and reported comparable results of TAC and CSA in inducing remission in $70 \%$ and $82 \%$ of patients, respectively $(P=0.3)$ [33]. However, Choudhry et al. showed that significantly fewer children relapsed in the TAC-treated group compared to the 
CSA-treated group [34], suggesting superior efficacy of TAC over CSA.

Concerns exist regarding chronic nephrotoxicity with the use of long-term CNI. Continuation of CNIs for more than 2 to 5 years has been shown to be associated with renal toxicity $[32,35,36]$. In patients with steroid-dependent nephrotic syndrome (SDNS), chronic histologic lesions due to CNI use were reported in as high as $35-75 \%$ of patients on renal biopsy [37-40]. For SRNS, Fujinaga et al. performed protocol biopsies in six SRNS children who used CSA for more than 2 years, and $87 \%$ (5/6) had nephrotoxic histologic changes [41]. These figures, however, are not directly comparable because the time points to perform a renal biopsy are not uniform between the studies. Still, it appears that incidence of nephrotoxicity is higher in patients with SRNS compared to those with SDNS [42].

With regard to nephrotoxicity, TAC appears to have a lower potential risk [43], and a multicentre study on SRNS patients has suggested a better preserved, long-term renal function in the TAC-treated group compared to CSA treatment [13], showing less arteriolopathy and interstitial fibrosis on renal biopsy [14]. In the study by Prasad et al. [33], 45 children with SRNS treated with either CSA or TAC were compared for renal survival at 1, 2, 3, 4 and 5 years. The results demonstrated that TAC had significantly superior outcomes in terms of long-term renal function $(P=0.02)$ [33]. Moreover, a study by Delbet et al. in 21 paediatric SDNS patients on CNI for more than 12 months found relatively infrequent (only 1 out of 21) renal histology of CNI nephrotoxicity, which the authors explained by a greater use of TAC over CSA [43]. Furthermore, in an RCT with 124 renal transplant recipients, conversion from CSA to TAC resulted in stabilized serum creatinine levels (whereas the CSA-continuation group had a significantly greater rise in serum creatinine) and resulted in a sustained reduction of blood pressure, improvement in serum lipid profile and quality of life [44]. In contrast, another study on renal transplant recipients reported comparable incidence of arteriolopathy between TAC and CSA [45].

Nevertheless, most centres have changed their prescription pattern towards TAC, as it appears to exhibit better efficacy and less systemic side effects, particularly nephrotoxicity. In addition, compared to CSA, TAC has fewer cosmetic side effects, such as gingival hypertrophy and hirsutism [34]. RCTs comparing both agents with a long-term follow-up are necessary to specifically address these points, and generalizable recommendations may be extrapolated thereafter.

\section{Cyclophosphamide}

CPM is an alkylating agent lowering the immune response and thereby used in several autoimmune diseases. It has been proven effective in maintaining remission and reducing relapses in steroid-sensitive nephrotic syndrome (SSNS). For SRNS, however, a body of literature suggested its limited efficacy in inducing sustained remission $[8,9,46-50]$, and there are currently no RCTs advocating the use of CPM in SRNS. Instead, $\mathrm{CNIs}$ are accepted for superior efficacy to CPM in the management of SRNS. A comparative study on the treatment effects of CPM and CSA was performed in 127 children with SRNS. At 5 years of follow-up, a higher response rate has been observed in 65 children receiving CSA for 2 years compared to 62 patients assigned to CPM treatment for 3 to 6 months ( $70.8 \%$ vs. $51.6 \%, P=0.027$ ), and a relapse-free survival also favoured CSA over CPM (38.3 vs. 32.5 months, $p<0.001)$ [51]. Similarly, superior effects were seen with TAC, showing significantly shorter mean time to remission compared with CPM [29]. These findings were supported by a systematic review showing that CNIs significantly increased the number of patients achieving remission compared with CPM [30]. In this systematic review, CPM plus steroids had no benefit compared to steroid monotherapy [30]. Moreover, with its substantial side effect, spectrum needs to be considered, such as gonadal dysfunction, myelosuppression and increased long-term risk of malignancy [52]. Thus, the use of CPM for SRNS is rather discouraged and officially not recommended by the KDIGO guidelines (Table 1) [12].

\section{Mycophenolate mofetil}

Mycophenolate mofetil (MMF) modulates the immune response by inhibiting inosine monophosphate dehydrogenase, a key enzyme involved in purine biosynthesis [26], and thereby inducing selective inhibition of DNA replication in T and B lymphocytes [7].

MMF has been effectively used as a remission-maintaining and steroid-sparing agent for children with SSNS, including frequently-relapsing nephrotic syndrome (FRNS) or SDNS $[8,80]$. For SRNS, several observational studies using MMF have demonstrated complete remission in $23-62 \%$, partial remission in $25-37 \%$ and no response in $8-40 \%$ of patients, although the results were largely impacted by a high likelihood of publication bias due to small numbers of patients [12, $56,81,82]$. MMF has also been suggested to be effective in children with SRNS under the age of 2 years [56].

Contrastingly, in a large longitudinal study from the PodoNet registry, MMF monotherapy during the first year of disease onset in 612 SRNS patients led to no remission in most $(83.3 \%)$ cases [11]. However, it should be noted that the registry contains both immune-mediated and monogenic SRNS. In addition, an RCT including children and adults compared dexamethasone (high cumulative exposure) plus MMF (DEX/MMF) to CSA monotherapy [55], showing no benefit of the former over the latter. In this study, sustained response was reported in 33.3\% of subjects receiving DEX/ MMF and $45.9 \%$ in those receiving CSA [55]. A systematic review also found no statistically significant difference in the 
Table 1 Efficacy of treatment options used in the management of cases with SRNS

\begin{tabular}{|c|c|c|c|}
\hline Drug & $\begin{array}{l}\text { Dose } \\
\text { (may differ by centres) }\end{array}$ & Efficacy & Recommendation $^{\mathrm{a}}$ \\
\hline RAS inhibitors & - & $\begin{array}{l}\text { In } 40-50 \% \text { lowered PU }[53,54] \\
\text { CR in } 27 \%, P R \text { in } 21 \%[9]\end{array}$ & Yes $[7,8,53,54]$ \\
\hline Steroid pulse & $\begin{array}{l}30 \mathrm{mg} / \mathrm{kg} \text { (max. } 1 \mathrm{~g} \text { ) QOD } \\
\text { Mendoza protocol for } 82 \text { weeks }\end{array}$ & $\begin{array}{l}\text { No effect in } \sim 85 \%[9] \\
\text { CR or PR in } 33-53 \%[12,48,55] \\
\text { CR in } 7 \%, \text { PR in } 11 \%, \text { no effect in } 83 \%[11]\end{array}$ & No [9] \\
\hline Cyclophosphamide & $\begin{array}{l}\text { IV } 500 \mathrm{mg} / \mathrm{m}^{2} \\
\text { PO } 2 \mathrm{mg} / \mathrm{kg} / \mathrm{d} \\
\text { (max. cumulative dose } 168 \mathrm{mg} / \mathrm{kg} \text { ) }\end{array}$ & $\begin{array}{l}\text { No effect [12] } \\
\text { CR in } 9 \%, \text { PR in } 8 \%, \text { no effect in } 83 \% \text { [11] }\end{array}$ & No $[8,12]$ \\
\hline $\begin{array}{l}\text { Mycophenolate } \\
\text { mofetil }\end{array}$ & PO $1200 \mathrm{mg} / \mathrm{m}^{2} / \mathrm{d} \# 2$ & $\begin{array}{l}\text { CR } 23-62 \%, \text { PR } 25-37 \%[12,52,56] \\
\text { CR in } 8 \%, \text { PR in } 8 \%, \text { no effect in } 83 \%[11]\end{array}$ & $\begin{array}{l}\text { No for monotherapy }[11,30,55 \\
\text { Yes for triple therapy }[57]\end{array}$ \\
\hline Calcineurin inhibitors & $\begin{array}{l}\text { Cyclosporine } 4-6 \mathrm{mg} / \mathrm{kg} / \text { day \#2 } \\
\text { (trough } 150-300 \mathrm{mg} / \mathrm{ml} \text { ) } \\
\text { Tacrolimus } 0.1-0.2 \mathrm{mg} / \mathrm{kg} / \text { day \#2 } \\
\text { (trough } 5-15 \mu \mathrm{g} / \mathrm{ml} \text { ) }\end{array}$ & $\begin{array}{l}\mathrm{CR} \text { or } \mathrm{PR} \text { in } 70 \%[7] \\
\mathrm{CR} \text { or } \mathrm{PR} \text { in } 50-70 \%[7] \\
\mathrm{CR} \text { or } \mathrm{PR} \text { in } 30-80 \%[28] \\
\mathrm{CR} \text { in } 30 \%, \mathrm{PR} \text { in } 19 \%[11]\end{array}$ & Yes $[7,28,30]$ \\
\hline Rituximab & IV $375 \mathrm{mg} / \mathrm{m}^{2}$ weekly or biweekly & $\begin{array}{l}\mathrm{CR} \text { in } 44 \%, \mathrm{PR} \text { in } 15 \%[9] \\
\mathrm{CR} \text { or PR in } 46 \%[58] \\
\text { No benefit [59] }\end{array}$ & $\begin{array}{l}\text { Yes }[60-62] \\
\text { No }[59,63]\end{array}$ \\
\hline Ofatumumab & $\begin{array}{l}\text { Variable } \\
300 \mathrm{mg} / 1.73 \mathrm{~m}^{2} \rightarrow 2000 \mathrm{mg} / 1.73 \mathrm{~m}^{2} \\
{[64]} \\
750 \mathrm{mg} / 1.73 \mathrm{~m}^{2}[65] \\
300 \mathrm{mg} / 1.73 \mathrm{~m}^{2}[66]\end{array}$ & $\begin{array}{l}\text { CR or PR in } 5 / 5 \text { pt. [67] } \\
\text { CR or PR in } 2 / 4 \text { pt. [68] } \\
\text { CR or PR in } 4 / 4 \text { pt. [64] }\end{array}$ & Little evidence \\
\hline Abatacept/Belatacept & Abatacept $10 \mathrm{mg} / \mathrm{kg}$ once or twice daily & $\begin{array}{l}\text { CR or PR in } 5 \text { pt. [69] } \\
\text { No effect in } 1 \text { pt. [70] }\end{array}$ & Little evidence \\
\hline $\begin{array}{l}\text { Adalimumab } \\
(\mathrm{mAb} \text { TNF- } \alpha)\end{array}$ & SC $24 \mathrm{mg} / \mathrm{m}^{2}$ (max.40 mg) biweekly & $\begin{array}{l}\text { Phase I trial: PR in } 40 \% \text { [71] } \\
\text { Phase II trial: no response [72] }\end{array}$ & No (Phase II) [53] \\
\hline $\begin{array}{l}\text { Fresolimumab } \\
(\mathrm{mAb} \text { TGF- } \beta)\end{array}$ & $1 \mathrm{mg} / \mathrm{kg}$ or $4 \mathrm{mg} / \mathrm{kg}$ & $\begin{array}{l}\text { Phase I trial: CR or PR in 18\% [53] } \\
\text { Phase II trial: no response [73] }\end{array}$ & No (Phase II) [73] \\
\hline Galactose & PO $0.2 \mathrm{~g} / \mathrm{kg}$ (max.15 g) twice daily & $\begin{array}{l}\text { Phase II trial: CR or PR in } 40 \%[72] \\
\text { PR in } 29 \%[72,74,75] \\
\text { No effect in PU }[76]\end{array}$ & Yes (Phase II) [72] \\
\hline ACTH analogues & $\begin{array}{l}\text { Gel } 80 \mathrm{U} / 1.73 \mathrm{~m}^{2} \text { twice weekly } \\
\text { IM } 1 \mathrm{mg} \text { weekly } \times 12 \text { months }\end{array}$ & $\begin{array}{l}\mathrm{PR} \text { in } 29 \%[77] \\
\mathrm{CR} \text { in } 33 \%(6 / 18) \text { and } \mathrm{PR} \text { in } 22 \%(4 / 18)[78]\end{array}$ & Little evidence \\
\hline Sparsentan & $200,400,800 \mathrm{mg} / \mathrm{d}$ & $\begin{array}{l}\text { More efficacious than irbesartan after } 8 \text { weeks } \\
\text { [79] }\end{array}$ & Little evidence \\
\hline
\end{tabular}

$C R$ complete remission; $P R$ partial remission; $m A b$ monoclonal antibody; $I V$ intravenous; $P O$ per oral; $S C$ subcutaneous; $Q O D$ every other day

${ }^{a}$ Recommended by one of the followings: systematic reviews, meta-analysis, official guidelines, reviews, phase I or II clinical trials

number of remissions between a combination of $\mathrm{MMF} /$ steroids to CSA or TAC monotherapy [30]. Moreover, an open-label RCT demonstrated that MMF was inferior to TAC in sustaining remission in 60 children with SRNS [32]. In this study, in patients who had previously achieved complete or partial remission using TAC, a switch from TAC to MMF at 6 months failed to maintain remission, yielding a twofold increased incidence of relapses and leading to higher prednisolone exposure [32].

Still, MMF is sometimes preferred for its relative safety with respect to nephrotoxicity. In the National Institutes of Health (NIH)-funded FSGS study, the authors reported a significantly lower median glomerular filtration rate (GFR) at 6 months after treatment in FSGS patients receiving CSA compared with those receiving DEX/MMF [55], which was further supported by an RCT in SSNS [83]. However, an RCT in children with SRNS showed no difference in GFR between MMF- and TAC-treated patients [32].

In general, the efficacy of MMF in patients with SRNS appears less satisfactory than in those with SSNS [32] and seems not superior to CNI monotherapy in SRNS. Nevertheless, MMF can be effective as an additive agent in maintaining CNI-induced [84-86] and rituximab (RTX)-induced remission [87] in SRNS patients, although premature switching to MMF is not recommended [32]. MMF may also be an alternative in patients who are resistant to CNI, which will be discussed below.

\section{Levamisole}

Levamisole is an immune-modulating anthelminthic that has been considered the least toxic and least expensive steroid- 
sparing agent for preventing relapses in SSNS [88]. Levamisole is a synthetic imidazole derivative which, instead of suppressing immunity, enhances humoral immune response and macrophage activation [89] and induces type 1 (Th1) and type 2 (Th2) T-cell responses through enhancing IL-18 activity [90]. In a human podocyte model, levamisole was shown to induce expression of glucocorticoid receptor, and it has been suggested that glucocorticoid signalling is a critical target of levamisole action [91].

Levamisole was shown to be effective in reducing the frequency of relapses in adult patients with SSNS [91], which was supported by a systematic review of RCTs [92]. In children with SSNS, a recent open-label RCT showed that levamisole had comparable and satisfactory efficacy compared to MMF in maintaining sustained remission [93].

With respect to SRNS, however, there is a paucity of data supporting the use of levamisole. In their experience with levamisole treatment in children with SSNS and SRNS, Tenbrock et al. concluded that levamisole had a clinical benefit in SSNS but not in SRNS [94]. Few studies thereafter have been performed in SRNS. In short, the efficacy of levamisole in SRNS so far appears limited.

\section{mTOR inhibitors}

Mammalian target of rapamycin (mTOR) signalling is involved in a variety of kidney diseases. mTOR inhibitors are assumed to work through control of autophagy [95]. They block T-cell proliferation and bind to the same immunomodulators as TAC, without affecting the activity of calcineurin [96]. Low-dose rapamycin, an inhibitor of the mTOR, has been reported to diminish disease progression in an experimental model of FSGS [97]. Rapamycin has been successfully used in a case series including three patients with FSGS [98] and in ten children with SRNS [96]. Moreover, in a prospective, open-label trial of sirolimus to treat steroid-resistant FSGS, complete or partial remission was reported in $47 \%$ of the treated patients [99]. However, a phase II open-label clinical trial study on sirolimus had to be prematurely discontinued due to renal functional deterioration after administration [100]. In addition, mTOR inhibitors at high dose may rather cause aggravation of proteinuria in FSGS [100]. Given their potential detrimental renal effects, the use of mTOR inhibitors in cases of SRNS is discouraged.

\section{Therapy for CNI-dependent or CNI-resistant SRNS}

A subset of SRNS patients is CNI-dependent, who respond to CNI treatment but relapse once therapy is tapered or discontinued, and another proportion is resistant to CNI. Since prolonged use of high-dose CNI can result in undesirable side effects (i.e. nephrotoxicity), alternative or additive drugs have been sought.
El-Reshaid et al. treated 21 CNI-resistant SRNS patients with CNI in combination with MMF and monthly intravenous $\mathrm{CPM}$ for a total of 3 pulses and induced complete remission in $71 \%(15 / 21)$ [101]. Former triple therapy approaches comprised CNI plus prednisolone and a third agent, such as MMF [102, 103] or mizoribine [104] (Table 2). Of these, MMF may be an effective third agent, supported by additional reports which show that remission was achieved in 20 to $50 \%$ of patients refractory to treatment with CNIs and corticosteroids $[32,105,106]$. Some retrospective case series have also showed that MMF, as a maintenance agent, enabled CNI- and steroid-free remission in some patients with CNI dependence and/or toxicity $[32,107,108]$. Still, as discussed in the previous section of this review, MMF as a monotherapy or in dual combination with prednisolone was not superior to CNIs in terms of inducing remission in SRNS [30, 32]. Wu et al. then performed a prospective RCT in 18 children with steroid- and TAC-resistant or TAC-dependent nephrotic syndrome [57]. They reported that triple-combination therapy with prednisolone, TAC and one out of MMF, CPM or leflunomide was effective for short-term response and remission at 1 year, with comparable efficacy between the three agents and without significant side effects [57]. However, prolonged intensive immunosuppression with a combined regimen may predispose patients to serious infectious complications and potential malignancy risk in the long term, and this should be closely monitored. Therefore, novel agents that could be used for a shorter period of time as pulse therapy have been sought, namely, monoclonal antibodies.

\section{Anti-CD20 monoclonal antibodies}

\section{Rituximab and novel CD20-blocking agents}

Multidrug-resistant patients who are unresponsive to above listed agents - steroids, CNI and MMF - pose a great challenge for nephrologists. Monoclonal antibodies have been investigated as salvage therapy for these patients.

Rituximab (RTX) is a chimeric anti-CD20 monoclonal antibody which has been used as an alternative steroid-sparing agent for SSNS patients since the early 2000s and is generally well tolerated. Its main action on immune regulation is through targeting the cell surface antigen CD20 on B lymphocytes and inducing B-cell depletion [26]. In addition, a nonimmune-related mechanism of action has been proposed. RTX reportedly could affect podocyte function through stabilization of sphingomyelin phosphodiesterase acid-like $3 \mathrm{~b}$ (SMPDL-3b), preventing podocyte actin remodelling [109].

While RTX has been successfully used in patients with FRNS or SDNS in recent years [110], a comparative study by Topaloglu et al. explored the effects of RTX in children with SSNS $(n=21)$ and SRNS $(n=20)$ and concluded that 
Table 2 Combination treatment for CNI-resistant or CNI-dependent SRNS

\begin{tabular}{|c|c|c|c|c|}
\hline Ref & Patients & Agents & Response & $\mathrm{F}-\mathrm{U}$ \\
\hline $\begin{array}{l}\text { Wu, } \\
2015[105]\end{array}$ & $\begin{array}{l}10 \text { TAC-resistant children } \\
8 \text { TAC-dependent children }\end{array}$ & $\begin{array}{l}\mathrm{Pd}+\mathrm{TAC}+\mathrm{MMF} / \mathrm{CPM} / \text { leflunomide } \\
\text { (3rd agents had equal efficacy) }\end{array}$ & $\begin{array}{l}\text { Short term response } 14 / 18(78 \%) \\
\text { Long-term remission } 11 / 18(61 \%)\end{array}$ & $5 \mathrm{yr}$ \\
\hline $\begin{array}{l}\text { El-Reshaid, } \\
2005 \text { [97] }\end{array}$ & 21 CNI-resistant MCD/FSGS & $\mathrm{CNI}+\mathrm{MMF}+\mathrm{IV} \mathrm{CPM}$ (for 3 months) & Complete remission $15 / 21(71 \%)$ & $6.5 \mathrm{yr}$ \\
\hline $\begin{array}{l}\text { Ballarin, } \\
2007[98]\end{array}$ & 9 adults with MGN & $\mathrm{Pd}+\mathrm{TAC}+\mathrm{MMF}$ & $\begin{array}{l}\text { Complete remission } 2 / 9 \\
\text { Partial remission } 3 / 9\end{array}$ & $23.1 \mathrm{mo}$ \\
\hline $\begin{array}{l}\text { Oki, } \\
2009[100]\end{array}$ & 2 CSA-resistant children & $\mathrm{Pd}+\mathrm{TAC}+$ mizoribine & $2 / 2$ complete remission & $8 \mathrm{mo}$ and $17 \mathrm{mo}$ \\
\hline Kim, 2014 [99] & 8 refractory SRNS & $\mathrm{Pd}+\mathrm{TAC}+\mathrm{MMF}$ & $75 \%$ response & N/A \\
\hline
\end{tabular}

$C R$ complete remission; $P R$ partial remission; TAC tacrolimus; $P d$ prednisolone, $M M F$ mycophenolate mofetil; $C P M$ cyclophosphamide; $F-U$ follow-up; $C N I$ calcineurin inhibitor; $M G N$ membranous glomerulonephropathy; $M C D$ minimal change disease; $F S G S$ focal segmental glomerulosclerosis; $y r$ years; mo months; $N / A$ not available

RTX had more positive therapeutic effects in patients with SSNS than in those with SRNS [111].

Although controversial results exist related to its efficacy in SRNS, it has been generally successful in children with SRNS $[60,112]$. Reportedly, approximately $50 \%$ of patients with refractory SRNS respond to RTX [61], showing complete remission in $44 \%$ and partial remission in $15 \%$ [9] of cases. Studies with more favourable outcomes report response rates of $63 \%$ [113], 67\% [87] and 80\% [62]. However, contrastingly, non-response rates of $81 \%$ [63] and $71 \%$ [112] were found by other publications. A recent systematic review of RCTs reported remission with RTX in $46 \%$ of SRNS $(63 \%$ with MCD and 39\% with FSGS) and sustained remission among responders in up to $\sim 94 \%$ [58]. However, an open-label RCT in patients with refractory SRNS by Magnasco et al. demonstrated no additional benefit of RTX over CNI [63].

There is a recent study by Fujinaga et al. reporting 100\% complete remission in children with SRNS receiving RTX [41]. This study is noteworthy because the authors emphasized the significance of timing of RTX initiation in SRNS patients. In the study, the authors investigated long-term outcomes after early application of RTX in six Japanese children who were unresponsive to a combination of CSA and intravenous methylprednisolone pulses [41]. The patients had RTX treatment within 6 months of disease onset (median 11 weeks), followed by retrial of high-dose intravenous methylprednisolone $(2 \mathrm{mg} / \mathrm{kg} / \mathrm{d})$ and oral prednisolone and then switched to maintenance oral immunosuppressants (MMF or CSA). Using this protocol, all six patients achieved complete remission at a median of 158 days and maintained remission (although there were relapses) for a follow-up period of 5.1 years, without developing renal insufficiency [41]. In the previous open-label RCT in patients with refractory SRNS by Magnasco et al., two standard doses of RTX were not able to induce remission within 3 months after administration [63]. It is important to note that in the study by Fujinaga, most patients $(4 / 6,67 \%)$ achieved remission after 3 months of RTX administration with repeated doses (one patient required eight doses of RTX until complete remission was achieved) [41]. The authors suggested that in case of unresponsiveness, repeated administration over a longer period of time can be effective in SRNS. Evidence supports the concept that serum RTX levels may decrease more rapidly in SRNS due to persistent urinary losses $[114,115]$. In that sense, it appears to require more doses in SRNS patients who have uncontrolled proteinuria $[41,116]$. Moreover, the time from diagnosis of SRNS to the first RTX infusion was 2.5 years in the RCT by Magnasco et al. [63] and 2.2 years in the study by Topaloglu et al. [111], while it was 11 months in Fujinaga et al.'s study [41]. It may be speculated that a long-lasting nephrotic state leads to irreversible histologic changes, such as fibrosis and glomerulosclerosis [41], which results in imperfect response to RTX treatment. This view was supported by an observational study by Kamei et al., in which seven out of ten (70\%) SRNS patients responded after repeated doses of RTX followed by intravenous methylprednisolone pulses and an additional oral immunosuppressant [62]. In this study, the seven patients who received RTX within 6 months of disease onset achieved complete remission, while two patients who had a longer duration of disease (61 and 121 months, respectively) progressed to end-stage kidney disease [41, 62].

Although rituximab is generally safe and well tolerated in most children, there are potentially serious adverse events that require caution: hypogammaglobulinemia, late-onset neutropenia, hepatitis $B$ reactivation, serious infusion-related adverse events and infections, the latter with potentially fatal outcome with reports of Pneumocystis jirovecii pneumonia and progressive multifocal leukoencephalopathy $[8,58,59$, $61,62,117,118]$. In the study by Fujinaga et al., although all six patients achieved complete remission, four of the six had hypogammaglobulinemia requiring intravenous immunoglobulins (IVIG), and one of them developed persistent hypogammaglobulinemia demanding regular IVIG treatment (despite re-emergence of B-cells in the blood) [41]. Such 
hematologic adverse effects are reported more often and more severely in younger children. In previous studies with SRNS [41] as well as with SDNS [119], those patients who developed severe neutropenia and hypogammaglobulinemia were aged under 10 years. In addition, in a Japanese multicentre study involving 114 children, the median age was significantly younger in patients with more severe hematologic adverse effects ( 6.4 vs. 11.5 years) [120]. On the other hand, Bonanni et al. reported only 2 cases of severe neutropenia out of 100 Caucasian children with multidrug-resistant nephrotic syndrome who received RTX [121]. This discrepancy may be explained by the older age of patients in Bonanni's group (median 9.2 years). Although the mechanisms leading to more complications in younger children are not well understood, younger age appears to be a particular risk factor for these adverse events.

To summarize, although RTX treatment in SRNS may not be as effective as in SSNS, early repeated administration with higher cumulative doses can be efficacious in the management SRNS. Early administration within 6 months of disease onset and a trial of multiple doses followed by methylprednisolone pulses with high-dose prednisolone showed favourable renal outcome. Adverse hematologic effects occur more frequently in children aged under 10.

\section{Ofatumumab}

Ofatumumab, a novel humanized anti-CD20 monoclonal antibody, is an alternative to RTX in patients with anti-RTX antibodies or RTX hypersensitivity. It has also been used in patients with resistance to RTX $[64,67,68]$ including cases with post-transplantation RTX-resistant SRNS [64, 122]. Ofatumumab successfully achieved remission in paediatric SRNS with severe adverse reactions to RTX [65] and antiRTX antibodies [66]. Efficacy of ofatumumab so far is exceptionally positive; its first use reported complete or partial remission in five out of five children with SRNS [67] and in a more recent study in four out of four children with SRNS who completed ofatumumab treatment [64]. In the latter study, two patients experienced hypersensitivity to ofatumumab and received desensitization [64]. In a study with lower doses of ofatumumab, two out of four patients who were resistant to a combination or steroids, CNIs and MMF, achieved remission [68].

The side effects, however, were more prevalent with ofatumumab than RTX in the study by Bonanni et al. [121]. They investigated treatment outcomes in steroid- and multidrug-dependent nephrotic syndrome using RTX in 137 and ofatumumab in 37 patients. While treatment efficacy was comparable, infusion reactions, such as skin rash, fever, dyspnoea and late adverse effects, were more frequent in the ofatumumab treatment group [121]. In this study, immediate infusion reactions were effectively controlled by pretreatment including steroids, antihistamines and paracetamol, and salbutamol was critical for preventing respiratory complications.

In short, ofatumumab is an emerging substitute for RTXresistant and RTX-hypersensitive patients with multidrugresistant SRNS, although adverse effects and infusion reactions are more common than following RTX administration. Addition of a beta-mimetic agent in the pretreatment protocol was helpful in controlling respiratory reaction.

\section{Other monoclonal antibodies}

There are a handful of novel monoclonal antibodies which have been used as potentially effective measures in nephrotic syndrome. Most of these, however, have been ineffective in SRNS, and only a few studies exist on paediatric patients.

\section{Abatacept/Belatacept}

Abatacept, a cytotoxic T-lymphocyte-associated protein 4 (CTLA-4) immunoglobulin (Ig), blocks the CD28:CD80/ CD86 co-stimulatory pathway and has recently been introduced as a treatment option for FSGS. A study by $\mathrm{Yu}$ et al. showed that B7-1 (CD80) overexpression was induced in podocytes in primary and recurrent FSGS and reported the efficacy of abatacept in four post-transplantation patients (two adults and two children) with recurrent FSGS refractory to immunosuppression including rituximab, and one adult patient with FSGS in the native kidney [69]. Controversies remain, since B7-1 (CD80) expression on podocytes has not been reproducible by different research groups [123, 124] and further research has showed no efficacy of abatacept in the management of FSGS/SRNS [70, 125]. Further prospective studies are on their way to prove or disprove the efficacy of abatacept in SRNS. The effects of belatacept, an agent with a higher potential to block B7-2 (CD86), also need to be further addressed.

\section{Adalimumab}

Adalimumab is a monoclonal antibody blocking TNF- $\alpha$ [26]. In the FONT phase 1 trial of adalimumab, four out of ten patients (mean age, 16.8 \pm 9.0 years) with primary FSGS showed a $>50 \%$ reduction in proteinuria, achieving partial remission during a 16-week treatment course [71]. To further test the hypothesis of adalimumab efficacy in FSGS, the FONT study group performed a phase II trial including 21 patients (14 children and 7 adults) with primary FSGS [72]. In the phase II trial, however, none of the subjects assigned to adalimumab achieved a 50\% reduction in proteinuria [72]. These findings suggest that adalimumab may not be effective in the management of FSGS/SRNS. 


\section{Fresolimumab}

Fresolimumab is a monoclonal antibody targeting transforming growth factor- $\beta$ (TGF- $\beta$ ). Sustained overproduction of TGF- $\beta$ has been implicated in the pathogenesis of fibrosis, including human fibrotic kidney diseases and FSGS [73]. In a phase I clinical trial, complete or partial remission was achieved in 3 out of 16 adults (mean age, $37 \pm$ 12 years) with primary FSGS who were previously unresponsive to CNIs or high-dose steroids, showing a response rate of $18 \%$ [53].

In the subsequent phase II trial with fresolimumab for 112 days, however, none of the 36 patients showed a > $50 \%$ decline in proteinuria compared to baseline [73]. The study was prematurely terminated due to futility, since a total recruitment of 88 patients was planned [73]. Three patients had some degree of decline in proteinuria but not meeting the criteria for remission, and fresolimumab was generally well tolerated [73]. Although the studies may have been underpowered, fresolimumab is no alternative in treating SRNS.

\section{Non-immunologic therapies}

\section{Renin angiotensin aldosterone system (RAS) inhibition}

Treatment with drugs that inhibit the renin-angiotensin axis has been recommended for children with SRNS by most of the previous reviews $[7,8,26]$. The response rate of RAS inhibition to lower proteinuria is reportedly around $40-50 \%$ in children with SRNS $[9,54,56]$. Furthermore, an RCT in 25 children with SRNS compared the efficacy of enalapril starting at low dose vs. starting at high dose [54]. The patients received concomitant steroids but no other immunosuppressants. In this study, the high-dose enalapril group showed significantly higher rates of proteinuria reduction (33\% vs. 52\%). Another RCT involving 45 children with SRNS demonstrated that fosinopril in combination with prednisolone significantly reduced proteinuria compared to prednisolone monotherapy [126]. In addition, there was a case report showing that RAS inhibition can be powerful in infantile SRNS as well, in which the authors reported complete remission by using RAS inhibition and supportive care in a 9-month-old patient with FSGS unresponsive to immunosuppression [127]. The patient was screened negative for NPHS1, NPHS2 and PLCE1 and was not tested for other genes at that time.

In short, angiotensin-converting enzyme inhibitors or angiotensin II receptor blockers are favourable for children with SRNS and are recommended by current guidelines $[12,31]$.

\section{Sparsentan}

Endothelin type A (ETA) receptor antagonists have emerged as promising therapies that may enhance RAS inhibitory action $[79,128]$. Sparsentan is a dual endothelin type A (ETA) and angiotensin II type 1 receptor antagonist.

A randomized, double-blind, active-control, doseescalation study (DUET), a phase II study, compared the efficacy and safety of sparsentan against irbesartan in 96 patients (aged 8-75 years) with primary FSGS [79]. The results showed that sparsentan-treated patients had greater reductions in proteinuria than the irbesartan-treated group after 8 weeks of treatment [79]. Adverse events of sparsentan were comparable to irbesartan, showing that sparsentan was generally safe and well tolerated [79]. Although it requires further clinical experience, this novel agent seems to be a promising nonimmune modulating option for SRNS. Data focusing on paediatric patients are needed in the future.

\section{Galactose}

Galactose might reduce proteinuria by binding to putative circulating factors and inhibiting their activity [26, 78, 129]. Case reports in children and adults suggest that patients with FSGS/SRNS may benefit from orally given galactose $[74,75$, 129]. A prospective clinical trial using galactose in seven children with SRNS demonstrated histological improvement in kidney biopsies but no effect in reducing proteinuria [76]. Nevertheless, a more recent phase II clinical trial showed that three out of seven FSGS patients treated with oral galactose showed at least a 50\% reduction in proteinuria at 6 months after initiation and a sustained effect for 3-12 months after discontinuation of galactose [72], which raised the possibility of galactose as an adjuvant agent in treating SRNS (Table 1).

\section{ACTH analogues}

The exact mechanism of adrenocorticotropic hormone $(\mathrm{ACTH})$ in reducing proteinuria is not well elucidated. In an observational study, application of an ACTH analogue in gel form reduced proteinuria in 11 out of 21 patients with nephrotic syndrome [130]. However, it should be noted that subjects had a variety of different immunologic kidney diseases, including membranous nephropathy, membranoproliferative nephropathy minimal change disease, immunoglobulin A nephropathy and lupus nephritis [130]. Intramuscular application of low-dose ACTH has also been reported to be effective in a study of 18 adults with nephrotic syndrome, inducing complete remission in 33\% (6/18) and partial remission in $22 \%(4 / 18)$ [131]. In contrast, a recent paediatric RCT - The ATLANTIS randomized trial for adrenocorticotropic hormone for childhood nephrotic syndrome - has reported that twiceweekly administration of ACTH $\left(80 \mathrm{U} / 1.73 \mathrm{~m}^{2}\right)$ was not 
effective in preventing relapses in children with FRNS or SDNS [132]. With regard to SRNS, one study with 24 FSGS patients reported complete or partial remission in $29 \%$ (7/24) after initiation of ACTH gel treatment, suggesting its possibility as a treatment option [77]. However, the high expense of ACTH, the relative lack of evidence [133] and recent reports on its prescription having been influenced by financial conflict of interest $[134,135]$ should prevent hasty recommendations on this drug being made.

\section{Mesenchymal stem cells (MSCs)}

Mesenchymal stem cells (MSCs), known for their immunomodulatory and anti-inflammatory effects, have been considered as a potential therapeutic agent for treating immunerelated diseases, including nephrotic syndrome [136, 137]. Currently, a phase I open-label pilot study on safety and efficacy is ongoing (Allogenic AD-MSC Transplantation in Idiopathic Nephrotic Syndrome (NCT02382874)).

\section{Retinoids}

Retinoids are analogues of vitamin A that regulate cellular differentiation. It has been suggested that retinoids are capable of restoring podocyte structure in that they reduce proteinuria in animal models of kidney diseases [138]. A recently completed phase II trial on the efficacy of retinoids in patients with FSGS, however, reported no reduction in proteinuria in seven patients who completed isotretinoin treatment (NCT00098020).

\section{Treating monogenic SRNS}

Although monogenic SRNS is thought to be inherently nonimmune-based, some cases have been reported to at least partially respond to immunosuppression [27, 139-144]. Moreover, there are familial cases reported as monogenic SSNS or mixtures of SSNS and SRNS [15, 145-147]. A recent review by Saleem has addressed this issue and proposed some mechanisms that explain therapeutic efficacy in monogenic nephrotic syndrome: (1) the affected genes may play a role in the immune responses, or (2) mutations in podocytes may alter their response to immunosuppressants [15]. In addition, direct effects of corticosteroids [148] and CSA [149] on podocytes may explain the variable responses to immunosuppression in monogenic nephrotic syndrome.

Regarding the efficacy of CSA in genetic SRNS, there have been further reports from a few cohorts. Buscher et al. studied immunosuppression outcomes in 91 children with SRNS (including congenital nephrotic syndrome) and reported that patients with Wilms tumour suppressor gene 1 (WT1) mutations were more responsive to CSA [150]. They further compared the response to CSA in non-genetic and genetic SRNS in a larger scale involving 231 patients (131 monogenic SRNS including 60 congenital nephrotic syndromes) [151]. Therein, they documented response to CSA in 19\% of monogenic SRNS (3\% complete remission and $16 \%$ partial remission). In the PodoNet registry report, there were 74 patients with documented genetic SRNS, and 14 patients (19\%) showed response to immunosuppression [9].

Specific gene disorders can sometimes benefit from new therapeutic strategies. Mutations in the genes related to biosynthesis of Coenzyme Q $10\left(\mathrm{CoQ}_{10}\right.$, ubiquinone) cause primary $\mathrm{CoQ}_{10}$ deficiency resulting in various clinical phenotypes. A portion of these patients present with SRNS, often with extrarenal manifestations such as sensorineural hearing loss or neurologic deficit [152-156]. In monogenic SRNS related to primary $\mathrm{CoQ}_{10}$ deficiency, early initiation of $\mathrm{CoQ}_{10}$ supplementation has been reported to reduce proteinuria and delay disease progression $[157,158]$.

\section{Conclusions}

SRNS is a heterogeneous entity, and the treatment effects may differ by the aetiology. For immune-mediated SRNS, based on the results from prospective studies and RCTs, the combination of a CNI and an alternate-day corticosteroid may be the major strategy. TAC appears to achieve a higher remission rate compared to CSA and a lower degree of side effects including nephrotoxicity and gingival hypertrophy. MMF seems not superior to $\mathrm{CNI}$ as a monotherapy, but its use in combination with other measures may be considered in patients with CNIresistant or CNI-dependent SRNS. RTX is reported to be less effective in SRNS, but timely administration with repeated dosing has shown to induce favourable outcomes. For monogenic SRNS, CNIs can be used although not as efficacious as in immune-based SRNS. Monogenic SRNS associated with $\mathrm{CoQ}_{10}$ deficiency may benefit from $\mathrm{CoQ}_{10}$ supplementation. Other novel agents require further validation for efficacy and safety in managing children with SRNS.

Funding Information Open Access funding provided by Projekt DEAL.

Open Access This article is licensed under a Creative Commons Attribution 4.0 International License, which permits use, sharing, adaptation, distribution and reproduction in any medium or format, as long as you give appropriate credit to the original author(s) and the source, provide a link to the Creative Commons licence, and indicate if changes were made. The images or other third party material in this article are included in the article's Creative Commons licence, unless indicated otherwise in a credit line to the material. If material is not included in the article's Creative Commons licence and your intended use is not permitted by statutory regulation or exceeds the permitted use, you will need to obtain permission directly from the copyright holder. To view a copy of this licence, visit http://creativecommons.org/licenses/by/4.0/. 


\section{References}

1. Eddy AA, Symons JM (2003) Nephrotic syndrome in childhood. Lancet 362:629-639

2. Franke I, Aydin M, Kurylowicz L, Lopez CEL, Ganschow R, Lentze MJ, Born M (2019) Clinical course \& management of childhood nephrotic syndrome in Germany: a large epidemiological ESPED study. BMC Nephrol 20:45

3. Franke I, Aydin M, Llamas Lopez CE, Kurylowicz L, Ganschow R, Lentze M, Born M (2018) The incidence of the nephrotic syndrome in childhood in Germany. Clin Exp Nephrol 22:126-132

4. Dossier C, Lapidus N, Bayer F, Sellier-Leclerc AL, Boyer O, de Pontual L, May A, Nathanson S, Orzechowski C, Simon T, Carrat F, Deschenes G (2016) Epidemiology of idiopathic nephrotic syndrome in children: endemic or epidemic? Pediatr Nephrol 31: 2299-2308

5. Nandlal L, Naicker T, Bhimma R (2019) Nephrotic syndrome in South African children: changing perspectives in the new millennium. Kidney Int Rep 4:522-534

6. Kikunaga K, Ishikura K, Terano C, Sato M, Komaki F, Hamasaki Y, Sasaki S, Iijima K, Yoshikawa N, Nakanishi K, Nakazato H, Matsuyama T, Ando T, Ito S, Honda M, Japanese Pediatric Survey Holding Information of NEphrotic syndrome (JP-SHINE) study of the Japanese Study Group of Renal Disease in Children (2017) High incidence of idiopathic nephrotic syndrome in East Asian children: a nationwide survey in Japan (JP-SHINE study). Clin Exp Nephrol 21:651-657

7. Tullus K, Webb H, Bagga A (2018) Management of steroidresistant nephrotic syndrome in children and adolescents. Lancet Child Adolesc Health 2:880-890

8. Noone DG, Iijima K, Parekh R (2018) Idiopathic nephrotic syndrome in children. Lancet 392:61-74

9. Trautmann A, Lipska-Zietkiewicz BS, Schaefer F (2018) Exploring the clinical and genetic spectrum of steroid resistant nephrotic syndrome: the PodoNet registry. Front Pediatr 6:200

10. Warejko JK, Tan W, Daga A, Schapiro D, Lawson JA, Shril S, Lovric S, Ashraf S, Rao J, Hermle T, Jobst-Schwan T, Widmeier E, Majmundar AJ, Schneider R, Gee HY, Schmidt JM, Vivante A, van der Ven AT, Ityel H, Chen J, Sadowski CE, Kohl S, Pabst WL, Nakayama M, Somers MJG, Rodig NM, Daouk G, Baum M, Stein DR, Ferguson MA, Traum AZ, Soliman NA, Kari JA, El Desoky S, Fathy H, Zenker M, Bakkaloglu SA, Muller D, Noyan A, Ozaltin F, Cadnapaphornchai MA, Hashmi S, Hopcian J, Kopp JB, Benador N, Bockenhauer D, Bogdanovic R, Stajic N, Chernin G, Ettenger R, Fehrenbach H, Kemper M, Munarriz RL, Podracka L, Buscher R, Serdaroglu E, Tasic V, Mane S, Lifton RP, Braun DA, Hildebrandt F (2018) Whole exome sequencing of patients with steroid-resistant nephrotic syndrome. Clin J Am Soc Nephrol 13:53-62

11. Trautmann A, Schnaidt S, Lipska-Zietkiewicz BS, Bodria M, Ozaltin F, Emma F, Anarat A, Melk A, Azocar M, Oh J, Saeed B, Gheisari A, Caliskan S, Gellermann J, Higuita LMS, Jankauskiene A, Drozdz D, Mir S, Balat A, Szczepanska M, Paripovic D, Zurowska A, Bogdanovic R, Yilmaz A, Ranchin B, Baskin E, Erdogan O, Remuzzi G, Firszt-Adamczyk A, KuzmaMroczkowska E, Litwin M, Murer L, Tkaczyk M, Jardim H, Wasilewska A, Printza N, Fidan K, Simkova E, Borzecka H, Staude H, Hees K, Schaefer F, PodoNet Consortium (2017) Long-term outcome of steroid-resistant nephrotic syndrome in children. J Am Soc Nephrol 28:3055-3065

12. Lombel RM, Hodson EM, Gipson DS, Kidney Disease: Improving Global Outcomes (2013) Treatment of steroidresistant nephrotic syndrome in children: new guidelines from KDIGO. Pediatr Nephrol 28:409-414
13. Mekahli D, Liutkus A, Ranchin B, Yu A, Bessenay L, Girardin E, Van Damme-Lombaerts R, Palcoux JB, Cachat F, Lavocat MP, Bourdat-Michel G, Nobili F, Cochat P (2009) Long-term outcome of idiopathic steroid-resistant nephrotic syndrome: a multicenter study. Pediatr Nephrol 24:1525-1532

14. Nourbakhsh N, Mak RH (2017) Steroid-resistant nephrotic syndrome: past and current perspectives. Pediatric Health Med Ther 8:29-37

15. Saleem MA (2019) Molecular stratification of idiopathic nephrotic syndrome. Nat Rev Nephrol 15:750-765

16. Bierzynska A, McCarthy HJ, Soderquest K, Sen ES, Colby E, Ding WY, Nabhan MM, Kerecuk L, Hegde S, Hughes D, Marks S, Feather S, Jones C, Webb NJ, Ognjanovic M, Christian M, Gilbert RD, Sinha MD, Lord GM, Simpson M, Koziell AB, Welsh GI, Saleem MA (2017) Genomic and clinical profiling of a national nephrotic syndrome cohort advocates a precision medicine approach to disease management. Kidney Int 91:937-947

17. Sloka JS, Stefanelli M (2005) The mechanism of action of methylprednisolone in the treatment of multiple sclerosis. Mult Scler $11: 425-432$

18. The American Society of Health-System Pharmacists (2016) Methylprednisolone. Online Available at https:/wwwdrugscom/ monograph/methylprednisolonehtml - accessed December 2019

19. Griswold WR, Tune BM, Reznik VM, Vazquez M, Prime DJ, Brock P, Mendoza SA (1987) Treatment of childhood prednisone-resistant nephrotic syndrome and focal segmental glomerulosclerosis with intravenous methylprednisolone and oral alkylating agents. Nephron 46:73-77

20. Mendoza SA, Reznik VM, Griswold WR, Krensky AM, Yorgin PD, Tune BM (1990) Treatment of steroid-resistant focal segmental glomerulosclerosis with pulse methylprednisolone and alkylating agents. Pediatr Nephrol 4:303-307

21. Tune BM, Kirpekar R, Sibley RK, Reznik VM, Griswold WR, Mendoza SA (1995) Intravenous methylprednisolone and oral alkylating agent therapy of prednisone-resistant pediatric focal segmental glomerulosclerosis: a long-term follow-up. Clin Nephrol 43:84-88

22. Yorgin PD, Krasher J, Al-Uzri AY (2001) Pulse methylprednisolone treatment of idiopathic steroid-resistant nephrotic syndrome. Pediatr Nephrol 16:245-250

23. Mori K, Honda M, Ikeda M (2004) Efficacy of methylprednisolone pulse therapy in steroid-resistant nephrotic syndrome. Pediatr Nephrol 19:1232-1236

24. Inaba A, Hamasaki $Y$, Ishikura $\mathrm{K}$, Hamada R, Sakai T, Hataya H, Komaki F, Kaneko T, Mori M, Honda M (2016) Long-term outcome of idiopathic steroid-resistant nephrotic syndrome in children. Pediatr Nephrol 31:425-434

25. Hinkes B, Vlangos C, Heeringa S, Mucha B, Gbadegesin R, Liu J, Hasselbacher K, Ozaltin F, Hildebrandt F; APN Study Group (2008) Specific podocin mutations correlate with age of onset in steroid-resistant nephrotic syndrome. J Am Soc Nephrol 19:365371

26. Dogra S, Kaskel F (2017) Steroid-resistant nephrotic syndrome: a persistent challenge for pediatric nephrology. Pediatr Nephrol 32: 965-974

27. Klaassen I, Ozgoren B, Sadowski CE, Moller K, van Husen M, Lehnhardt A, Timmermann K, Freudenberg F, Helmchen U, Oh J, Kemper MJ (2015) Response to cyclosporine in steroid-resistant nephrotic syndrome: discontinuation is possible. Pediatr Nephrol 30:1477-1483

28. Li S, Yang H, Guo P, Ao X, Wan J, Li Q, Tan L (2017) Efficacy and safety of immunosuppressive medications for steroid-resistant nephrotic syndrome in children: a systematic review and network meta-analysis. Oncotarget 8:73050-73062

29. Gulati A, Sinha A, Gupta A, Kanitkar M, Sreenivas V, Sharma J, Mantan M, Agarwal I, Dinda AK, Hari P, Bagga A (2012) 
Treatment with tacrolimus and prednisolone is preferable to intravenous cyclophosphamide as the initial therapy for children with steroid-resistant nephrotic syndrome. Kidney Int 82:1130-1135

30. Hodson EM, Wong SC, Willis NS, Craig JC (2016) Interventions for idiopathic steroid-resistant nephrotic syndrome in children. Cochrane Database Syst Rev 10:CD003594

31. (2012) KDIGO clinical practice guideline for glomerulonephritis. Kidney Int Suppl 2:139-274

32. Sinha A, Gupta A, Kalaivani M, Hari P, Dinda AK, Bagga A (2017) Mycophenolate mofetil is inferior to tacrolimus in sustaining remission in children with idiopathic steroid-resistant nephrotic syndrome. Kidney Int 92:248-257

33. Prasad N, Manjunath R, Rangaswamy D, Jaiswal A, Agarwal V, Bhadauria D, Kaul A, Sharma R, Gupta A (2018) Efficacy and safety of cyclosporine versus tacrolimus in steroid and cyclophosphamide resistant nephrotic syndrome: a prospective study. Indian J Nephrol 28:46-52

34. Choudhry S, Bagga A, Hari P, Sharma S, Kalaivani M, Dinda A (2009) Efficacy and safety of tacrolimus versus cyclosporine in children with steroid-resistant nephrotic syndrome: a randomized controlled trial. Am J Kidney Dis 53:760-769

35. Sinha A, Sharma A, Mehta A, Gupta R, Gulati A, Hari P, Dinda AK, Bagga A (2013) Calcineurin inhibitor induced nephrotoxicity in steroid resistant nephrotic syndrome. Indian J Nephrol 23:4146

36. Hamasaki Y, Komaki F, Ishikura K, Hamada R, Sakai T, Hataya H, Ogata K, Ando T, Honda M (2017) Nephrotoxicity in children with frequently relapsing nephrotic syndrome receiving long-term cyclosporine treatment. Pediatr Nephrol 32:1383-1390

37. Iijima K, Hamahira K, Tanaka R, Kobayashi A, Nozu K, Nakamura H, Yoshikawa N (2002) Risk factors for cyclosporine-induced tubulointerstitial lesions in children with minimal change nephrotic syndrome. Kidney Int 61:1801-1805

38. Seikaly MG, Prashner H, Nolde-Hurlbert B, Browne R (2000) Long-term clinical and pathological effects of cyclosporin in children with nephrosis. Pediatr Nephrol 14:214-217

39. Fujinaga S, Kaneko K, Muto T, Ohtomo Y, Murakami H, Yamashiro Y (2006) Independent risk factors for chronic cyclosporine induced nephropathy in children with nephrotic syndrome. Arch Dis Child 91:666-670

40. Kim JH, Park SJ, Yoon SJ, Lim BJ, Jeong HJ, Lee JS, Kim PK, Shin JI (2011) Predictive factors for ciclosporin-associated nephrotoxicity in children with minimal change nephrotic syndrome. J Clin Pathol 64:516-519

41. Fujinaga S, Nishino T, Umeda C, Tomii Y, Watanabe Y, Sakuraya K (2019) Long-term outcomes after early treatment with rituximab for Japanese children with cyclosporine- and steroid-resistant nephrotic syndrome. Pediatr Nephrol 34:353-357

42. Niaudet P, Broyer M, Habib R (1991) Treatment of idiopathic nephrotic syndrome with cyclosporin a in children. Clin Nephrol 35(Suppl 1):S31-S36

43. Delbet JD, Aoun B, Buob D, Degheili J, Brocheriou I, Ulinski T (2019) Infrequent tacrolimus-induced nephrotoxicity in French patients with steroid-dependent nephrotic syndrome. Pediatr Nephrol 34:2605-2608

44. Artz MA, Boots JM, Ligtenberg G, Roodnat JI, Christiaans MH, Vos PF, Moons P, Borm G, Hilbrands LB (2004) Conversion from cyclosporine to tacrolimus improves quality-of-life indices, renal graft function and cardiovascular risk profile. Am J Transplant 4: 937-945

45. Nankivell BJ, P'Ng CH, O'Connell PJ, Chapman JR (2016) Calcineurin inhibitor nephrotoxicity through the lens of longitudinal histology: comparison of cyclosporine and tacrolimus eras. Transplantation 100:1723-1731
46. Bajpai A, Bagga A, Hari P, Dinda A, Srivastava RN (2003) Intravenous cyclophosphamide in steroid-resistant nephrotic syndrome. Pediatr Nephrol 18:351-356

47. Plank C, Kalb V, Hinkes B, Hildebrandt F, Gefeller O, Rascher W, Arbeitsgemeinschaft fur Padiatrische Nephrologie (2008) Cyclosporin a is superior to cyclophosphamide in children with steroid-resistant nephrotic syndrome-a randomized controlled multicentre trial by the Arbeitsgemeinschaft fur Padiatrische Nephrologie. Pediatr Nephrol 23:1483-1493

48. Tarshish P, Tobin JN, Bernstein J, Edelmann CM Jr (1996) Cyclophosphamide does not benefit patients with focal segmental glomerulosclerosis. A report of the international study of kidney disease in children. Pediatr Nephrol 10:590-593

49. Latta K, von Schnakenburg C, Ehrich JH (2001) A meta-analysis of cytotoxic treatment for frequently relapsing nephrotic syndrome in children. Pediatr Nephrol 16:271-282

50. Vester U, Kranz B, Zimmermann S, Hoyer PF (2003) Cyclophosphamide in steroid-sensitive nephrotic syndrome: outcome and outlook. Pediatr Nephrol 18:661-664

51. Liu Y, Yang R, Yang C, Dong S, Zhu Y, Zhao M, Yuan F, Gui K (2018) Cyclophosphamide versus cyclosporine a therapy in steroid-resistant nephrotic syndrome: a retrospective study with a mean 5-year follow-up. J Int Med Res 46:4506-4517

52. Lee JM, Kronbichler A, Shin JI, Oh J (2019) Review on long-term non-renal complications of childhood nephrotic syndrome. Acta Paediatr. https://doi.org/10.1111/apa.15035

53. Trachtman H, Fervenza FC, Gipson DS, Heering P, Jayne DR, Peters H, Rota S, Remuzzi G, Rump LC, Sellin LK, Heaton JP, Streisand JB, Hard ML, Ledbetter SR, Vincenti F (2011) A phase 1, single-dose study of fresolimumab, an anti-TGF-beta antibody, in treatment-resistant primary focal segmental glomerulosclerosis. Kidney Int 79:1236-1243

54. Bagga A, Mudigoudar BD, Hari P, Vasudev V (2004) Enalapril dosage in steroid-resistant nephrotic syndrome. Pediatr Nephrol 19:45-50

55. Gipson DS, Trachtman H, Kaskel FJ, Greene TH, Radeva MK, Gassman JJ, Moxey-Mims MM, Hogg RJ, Watkins SL, Fine RN, Hogan SL, Middleton JP, Vehaskari VM, Flynn PA, Powell LM, Vento SM, McMahan JL, Siegel N, D'Agati VD, Friedman AL (2011) Clinical trial of focal segmental glomerulosclerosis in children and young adults. Kidney Int 80:868-878

56. Li Z, Duan C, He J, Wu T, Xun M, Zhang Y, Yin Y (2010) Mycophenolate mofetil therapy for children with steroidresistant nephrotic syndrome. Pediatr Nephrol 25:883-888

57. Wu B, Mao J, Shen H, Fu H, Wang J, Liu A, Gu W, Shu Q, Du L (2015) Triple immunosuppressive therapy in steroid-resistant nephrotic syndrome children with tacrolimus resistance or tacrolimus sensitivity but frequently relapsing. Nephrology (Carlton) 20: $18-24$

58. Jellouli M, Charfi R, Maalej B, Mahfoud A, Trabelsi S, Gargah T (2018) Rituximab in the management of pediatric steroid-resistant nephrotic syndrome: a systematic review. J Pediatr 197(191-197): e191

59. Downie ML, Gallibois C, Parekh RS, Noone DG (2017) Nephrotic syndrome in infants and children: pathophysiology and management. Paediatr Int Child Health 37:248-258

60. Bagga A, Sinha A, Moudgil A (2007) Rituximab in patients with the steroid-resistant nephrotic syndrome. N Engl J Med 356:27512752

61. Kamei K, Ishikura K, Sako M, Ito S, Nozu K, Iijima K (2020) Rituximab therapy for refractory steroid-resistant nephrotic syndrome in children. Pediatr Nephrol 35:17-24

62. Kamei K, Okada M, Sato M, Fujimaru T, Ogura M, Nakayama M, Kaito H, Iijima K, Ito S (2014) Rituximab treatment combined with methylprednisolone pulse therapy and immunosuppressants 
for childhood steroid-resistant nephrotic syndrome. Pediatr Nephrol 29:1181-1187

63. Magnasco A, Ravani P, Edefonti A, Murer L, Ghio L, Belingheri M, Benetti E, Murtas C, Messina G, Massella L, Porcellini MG, Montagna M, Regazzi M, Scolari F, Ghiggeri GM (2012) Rituximab in children with resistant idiopathic nephrotic syndrome. J Am Soc Nephrol 23:1117-1124

64. Wang CS, Liverman RS, Garro R, George RP, Glumova A, Karp A, Jernigan S, Warshaw B (2017) Ofatumumab for the treatment of childhood nephrotic syndrome. Pediatr Nephrol 32:835-841

65. Vivarelli M, Colucci M, Bonanni A, Verzani M, Serafinelli J, Emma F, Ghiggeri G (2017) Ofatumumab in two pediatric nephrotic syndrome patients allergic to rituximab. Pediatr Nephrol 32:181-184

66. Fujinaga S, Sakuraya K (2018) Single infusion of low-dose ofatumumab in a child with complicated nephrotic syndrome with anti-rituximab antibodies. Pediatr Nephrol 33:527-528

67. Basu B (2014) Ofatumumab for rituximab-resistant nephrotic syndrome. N Engl J Med 370:1268-1270

68. Bonanni A, Rossi R, Murtas C (2015) Ghiggeri GM (2015) lowdose ofatumumab for rituximab-resistant nephrotic syndrome. BMJ Case Rep. https://doi.org/10.1136/bcr-2015-210208

69. Yu CC, Fornoni A, Weins A, Hakroush S, Maiguel D, Sageshima J, Chen L, Ciancio G, Faridi MH, Behr D, Campbell KN, Chang JM, Chen HC, Oh J, Faul C, Arnaout MA, Fiorina P, Gupta V, Greka A, Burke GW 3rd, Mundel P (2013) Abatacept in B7-1positive proteinuric kidney disease. N Engl J Med 369:2416-2423

70. Kristensen T, Ivarsen P, Povlsen JV (2017) Unsuccessful treatment with abatacept in recurrent focal segmental glomerulosclerosis after kidney transplantation. Case Rep Nephrol Dial 7:1-5

71. Joy MS, Gipson DS, Powell L, MacHardy J, Jennette JC, Vento S, Pan C, Savin V, Eddy A, Fogo AB, Kopp JB, Cattran D, Trachtman H (2010) Phase 1 trial of adalimumab in focal segmental glomerulosclerosis (FSGS): II. Report of the FONT (novel therapies for resistant FSGS) study group. Am J Kidney Dis 55: $50-60$

72. Trachtman H, Vento S, Herreshoff E, Radeva M, Gassman J, Stein DT, Savin VJ, Sharma M, Reiser J, Wei C, Somers M, Srivastava T, Gipson DS (2015) Efficacy of galactose and adalimumab in patients with resistant focal segmental glomerulosclerosis: report of the font clinical trial group. BMC Nephrol 16:111

73. Vincenti F, Fervenza FC, Campbell KN, Diaz M, Gesualdo L, Nelson P, Praga M, Radhakrishnan J, Sellin L, Singh A, Thornley-Brown D, Veronese FV, Accomando B, Engstrand S, Ledbetter S, Lin J, Neylan J, Tumlin J, Focal Segmental Glomerulosclerosis Study Group (2017) A phase 2, double-blind, placebo-controlled, randomized study of Fresolimumab in patients with steroid-resistant primary focal segmental glomerulosclerosis. Kidney Int Rep 2:800-810

74. De Smet E, Rioux JP, Ammann H, Deziel C, Querin S (2009) FSGS permeability factor-associated nephrotic syndrome: remission after oral galactose therapy. Nephrol Dial Transplant 24: 2938-2940

75. Kopac M, Meglic A, Rus RR (2011) Partial remission of resistant nephrotic syndrome after oral galactose therapy. Ther Apher Dial 15:269-272

76. Sgambat K, Banks M, Moudgil A (2013) Effect of galactose on glomerular permeability and proteinuria in steroid-resistant nephrotic syndrome. Pediatr Nephrol 28:2131-2135

77. Hogan J, Bomback AS, Mehta K, Canetta PA, Rao MK, Appel GB, Radhakrishnan J, Lafayette RA (2013) Treatment of idiopathic FSGS with adrenocorticotropic hormone gel. Clin J Am Soc Nephrol 8:2072-2081

78. Bierzynska A, Saleem M (2017) Recent advances in understanding and treating nephrotic syndrome. F1000Res 6:121
79. Trachtman H, Nelson P, Adler S, Campbell KN, Chaudhuri A, Derebail VK, Gambaro G, Gesualdo L, Gipson DS, Hogan J, Lieberman K, Marder B, Meyers KE, Mustafa E, Radhakrishnan J, Srivastava T, Stepanians M, Tesar V, Zhdanova O, Komers R, DUET Study Group (2018) DUET: a phase 2 study evaluating the efficacy and safety of sparsentan in patients with FSGS. J Am Soc Nephrol 29:2745-2754

80. Nandi M, Mandal SK, Samanta M, Majhi A, Das MK (2019) Efficacy of mycophenolate mofetil as a remission maintaining agent in idiopathic childhood nephrotic syndrome. Indian J Nephrol 29:34-41

81. de Mello VR, Rodrigues MT, Mastrocinque TH, Martins SP, de Andrade OV, Guidoni EB, Scheffer DK, Martini Filho D, Toporovski J, Benini V (2010) Mycophenolate mofetil in children with steroid/cyclophosphamide-resistant nephrotic syndrome. Pediatr Nephrol 25:453-460

82. Gargah TT, Lakhoua MR (2011) Mycophenolate mofetil in treatment of childhood steroid-resistant nephrotic syndrome. J Nephrol 24:203-207

83. Gellermann J, Weber L, Pape L, Tonshoff B, Hoyer P, Querfeld U, Gesellschaft für Pädiatrische Nephrologie (GPN) (2013) Mycophenolate mofetil versus cyclosporin a in children with frequently relapsing nephrotic syndrome. J Am Soc Nephrol 24: 1689-1697

84. Nickavar A, Safarzadeh AE, Sotoudeh K, Otukesh H, Hooman N (2012) Mycophenolate mofetil for treatment of idiopathic nephrotic syndrome in children. Iran J Kidney Dis 6:346-349

85. Ulinski T, Dubourg L, Said MH, Parchoux B, Ranchin B, Cochat $P$ (2005) Switch from cyclosporine a to mycophenolate mofetil in nephrotic children. Pediatr Nephrol 20:482-485

86. Okada M, Sugimoto K, Yagi K, Yanagida H, Tabata N, Takemura $\mathrm{T}$ (2007) Mycophenolate mofetil therapy for children with intractable nephrotic syndrome. Pediatr Int 49:933-937

87. Basu B, Mahapatra TK, Mondal N (2015) Mycophenolate mofetil following rituximab in children with steroid-resistant nephrotic syndrome. Pediatrics 136:e132-e139

88. Gruppen MP, Bouts AH, Jansen-van der Weide MC, Merkus MP, Zurowska A, Maternik M, Massella L, Emma F, Niaudet P, Cornelissen EAM, Schurmans T, Raes A, van de Walle J, van Dyck M, Gulati A, Bagga A, Davin JC (2018) A randomized clinical trial indicates that levamisole increases the time to relapse in children with steroid-sensitive idiopathic nephrotic syndrome. Kidney Int 93:510-518

89. Vivarelli M, Emma F (2019) Levamisole for children with nephrotic syndrome: new evidence for the use of an "old" drug. Kidney Int 95:25-28

90. Muhlig AK, Lee JY, Kemper MJ, Kronbichler A, Yang JW, Lee JM, Shin JI, Oh J (2019) Levamisole in children with idiopathic nephrotic syndrome: clinical efficacy and pathophysiological aspects. J Clin Med 8(6)

91. Jiang L, Dasgupta I, Hurcombe JA, Colyer HF, Mathieson PW, Welsh GI (2015) Levamisole in steroid-sensitive nephrotic syndrome: usefulness in adult patients and laboratory insights into mechanisms of action via direct action on the kidney podocyte. Clin Sci (Lond) 128:883-893

92. Hodson EM, Craig JC, Willis NS (2005) Evidence-based management of steroid-sensitive nephrotic syndrome. Pediatr Nephrol 20: $1523-1530$

93. Sinha A, Puraswani M, Kalaivani M, Goyal P, Hari P, Bagga A (2019) Efficacy and safety of mycophenolate mofetil versus levamisole in frequently relapsing nephrotic syndrome: an openlabel randomized controlled trial. Kidney Int 95:210-218

94. Tenbrock K, Muller-Berghaus J, Fuchshuber A, Michalk D, Querfeld U (1998) Levamisole treatment in steroid-sensitive and steroid-resistant nephrotic syndrome. Pediatr Nephrol 12:459-462 
95. Liu L, Yang L, Chang B, Zhang J, Guo Y, Yang X (2018) The protective effects of rapamycin on cell autophagy in the renal tissues of rats with diabetic nephropathy via mTOR-S6K1-LC3II signaling pathway. Ren Fail 40:492-497

96. Liern M, De Reyes V, Fayad A, Vallejo G (2012) Use of sirolimus in patients with primary steroid-resistant nephrotic syndrome. Nefrologia 32:321-328

97. Zschiedrich S, Bork T, Liang W, Wanner N, Eulenbruch K, Munder S, Hartleben B, Kretz O, Gerber S, Simons M, Viau A, Burtin M, Wei C, Reiser J, Herbach N, Rastaldi MP, Cohen CD, Tharaux PL, Terzi F, Walz G, Godel M, Huber TB (2017) Targeting mTOR signaling can prevent the progression of FSGS. J Am Soc Nephrol 28:2144-2157

98. Tsagalis G, Psimenou E, Iliadis A, Nakopoulou L, Laggouranis A (2009) Rapamycin for focal segmental glomerulosclerosis: a report of 3 cases. Am J Kidney Dis 54:340-344

99. Tumlin JA, Miller D, Near M, Selvaraj S, Hennigar R, Guasch A (2006) A prospective, open-label trial of sirolimus in the treatment of focal segmental glomerulosclerosis. Clin J Am Soc Nephrol 1: $109-116$

100. Cho ME, Hurley JK, Kopp JB (2007) Sirolimus therapy of focal segmental glomerulosclerosis is associated with nephrotoxicity. Am J Kidney Dis 49:310-317

101. El-Reshaid K, El-Reshaid W, Madda J (2005) Combination of immunosuppressive agents in treatment of steroid-resistant minimal change disease and primary focal segmental glomerulosclerosis. Ren Fail 27:523-530

102. Ballarin J, Poveda R, Ara J, Perez L, Calero F, Grinyo JM, Romero R (2007) Treatment of idiopathic membranous nephropathy with the combination of steroids, tacrolimus and mycophenolate mofetil: results of a pilot study. Nephrol Dial Transplant 22: 3196-3201

103. Kim J, Patnaik N, Chorny N, Frank R, Infante L, Sethna C (2014) Second-line immunosuppressive treatment of childhood nephrotic syndrome: a single-center experience. Nephron Extra 4:8-17

104. Oki E, Tsuruga K, Kudo M, Tsugawa K, Suzuki K, Tanaka H (2009) A novel multidrug therapy for difficult cyclosporineresistant focal segmental glomerulosclerosis. Pediatr Nephrol 24: 873-875

105. Hibino S, Uemura O, Nagai T, Yamakawa S, Iwata N, Ito H, Nakano M, Tanaka K (2015) Three year outcome of childhood idiopathic nephrotic syndrome under a unified immunosuppressive protocol. Pediatr Int 57:85-91

106. Nikibakhsh AA, Mahmoodzadeh H, Karamyyar M, Hejazi S, Noroozi M, Macooie AA (2011) Treatment of steroid and cyclosporine-resistant idiopathic nephrotic syndrome in children. Int J Nephrol 2011:930965

107. Gellermann J, Ehrich JH, Querfeld U (2012) Sequential maintenance therapy with cyclosporin a and mycophenolate mofetil for sustained remission of childhood steroid-resistant nephrotic syndrome. Nephrol Dial Transplant 27:1970-1978

108. Fujinaga S, Ohtomo Y, Umino D, Takemoto M, Shimizu T, Yamashiro Y, Kaneko K (2007) A prospective study on the use of mycophenolate mofetil in children with cyclosporinedependent nephrotic syndrome. Pediatr Nephrol 22:71-76

109. Fornoni A, Sageshima J, Wei C, Merscher-Gomez S, AguillonPrada R, Jauregui AN, Li J, Mattiazzi A, Ciancio G, Chen L, Zilleruelo G, Abitbol C, Chandar J, Seeherunvong W, Ricordi C, Ikehata M, Rastaldi MP, Reiser J, Burke GW 3rd (2011) Rituximab targets podocytes in recurrent focal segmental glomerulosclerosis. Sci Transl Med 3:85ra46

110. Iijima K, Sako M, Kamei K, Nozu K (2018) Rituximab in steroidsensitive nephrotic syndrome: lessons from clinical trials. Pediatr Nephrol 33:1449-1455

111. Topaloglu R, Gulhan B, Celegen K, Inozu M, Hayran M, Duzova A, Ozaltin F (2019) Rituximab for children with difficult-to-treat nephrotic syndrome: its effects on disease progression and growth. Front Pediatr 7:313

112. Sinha A, Bhatia D, Gulati A, Rawat M, Dinda AK, Hari P, Bagga A (2015) Efficacy and safety of rituximab in children with difficult-to-treat nephrotic syndrome. Nephrol Dial Transplant 30:96-106

113. Ito S, Kamei K, Ogura M, Udagawa T, Fujinaga S, Saito M, Sako M, Iijima K (2013) Survey of rituximab treatment for childhoodonset refractory nephrotic syndrome. Pediatr Nephrol 28:257-264

114. Fogueri U, Cheungapasitporn W, Bourne D, Fervenza FC, Joy MS (2019) Rituximab exhibits altered pharmacokinetics in patients with membranous nephropathy. Ann Pharmacother 53:357-363

115. Fervenza FC, Abraham RS, Erickson SB, Irazabal MV, Eirin A, Specks U, Nachman PH, Bergstralh EJ, Leung N, Cosio FG, Hogan MC, Dillon JJ, Hickson LJ, Li X, Cattran DC, Mayo Nephrology Collaborative Group (2010) Rituximab therapy in idiopathic membranous nephropathy: a 2-year study. Clin J Am Soc Nephrol 5:2188-2198

116. Seitz-Polski B, Dahan K, Debiec H, Rousseau A, Andreani M, Zaghrini C, Ticchioni M, Rosenthal A, Benzaken S, Bernard G, Lambeau G, Ronco P, Esnault VLM (2019) High-dose rituximab and early remission in PLA2R1-related membranous nephropathy. Clin J Am Soc Nephrol 14:1173-1182

117. Iijima K, Sako M, Nozu K (2017) Rituximab for nephrotic syndrome in children. Clin Exp Nephrol 21:193-202

118. Kronbichler A, Windpessl M, Pieringer H, Jayne DRW (2017) Rituximab for immunologic renal disease: what the nephrologist needs to know. Autoimmun Rev 16:633-643

119. Fujinaga S, Ozawa K, Sakuraya K, Yamada A, Shimizu T (2016) Late-onset adverse events after a single dose of rituximab in children with complicated steroid-dependent nephrotic syndrome. Clin Nephrol 85:340-345

120. Kamei K, Takahashi M, Fuyama M, Saida K, Machida H, Sato M, Ogura M, Ito S (2015) Rituximab-associated agranulocytosis in children with refractory idiopathic nephrotic syndrome: case series and review of literature. Nephrol Dial Transplant 30:91-96

121. Bonanni A, Calatroni M, D’Alessandro M, Signa S, Bertelli E, Cioni M, Di Marco E, Biassoni R, Caridi G, Ingrasciotta G, Bertelli R, Di Donato A, Bruschi M, Canepa A, Piaggio G, Ravani P, Ghiggeri GM (2018) Adverse events linked with the use of chimeric and humanized anti-CD20 antibodies in children with idiopathic nephrotic syndrome. Br J Clin Pharmacol 84: 1238-1249

122. Bernard J, Bruel A, Allain-Launay E, Dantal J, Roussey G (2018) Ofatumumab in post-transplantation recurrence of a pediatric steroid-resistant idiopathic nephrotic syndrome. Pediatr Transplant 22:e13175

123. Novelli R, Benigni A, Remuzzi G (2018) The role of B7-1 in proteinuria of glomerular origin. Nat Rev Nephrol 14:589-596

124. Benigni A, Gagliardini E, Remuzzi G (2014) Abatacept in B7-1positive proteinuric kidney disease. N Engl J Med 370:1261-1263

125. Delville M, Baye E, Durrbach A, Audard V, Kofman T, Braun L, Olagne J, Nguyen C, Deschenes G, Moulin B, Delahousse M, Kesler-Roussey G, Beaudreuil S, Martinez F, Rabant M, Grimbert P, Gallazzini M, Terzi F, Legendre C, Canaud G (2016) B7-1 blockade does not improve post-transplant nephrotic syndrome caused by recurrent FSGS. J Am Soc Nephrol 27:2520 2527

126. Yi Z, Li Z, Wu XC, He QN, Dang XQ, He XJ (2006) Effect of fosinopril in children with steroid-resistant idiopathic nephrotic syndrome. Pediatr Nephrol 21:967-972

127. Soliman NA, Francis M, Heeringa SF, Chernin G (2009) Complete remission of nephrotic syndrome in an infant with focal segmental glomerulosclerosis: is it renin-angiotensin blockade? Pediatr Nephrol 24:1065-1070 
128. Komers R, Gipson DS, Nelson P, Adler S, Srivastava T, Derebail VK, Meyers KE, Pergola P, MacNally ME, Hunt JL, Shih A, Trachtman H (2017) Efficacy and safety of sparsentan compared with Irbesartan in patients with primary focal segmental glomerulosclerosis: randomized, controlled trial design (DUET). Kidney Int Rep 2:654-664

129. Savin VJ, McCarthy ET, Sharma R, Charba D, Sharma M (2008) Galactose binds to focal segmental glomerulosclerosis permeability factor and inhibits its activity. Transl Res 151:288-292

130. Bomback AS, Radhakrishnan J (2011) Treatment of nephrotic syndrome with adrenocorticotropic hormone (ACTH). Discov Med 12:91-96

131. Lorusso P, Bottai A, Mangione E, Innocenti M, Cupisti A, Egidi MF (2015) Low-dose synthetic adrenocorticotropic hormoneanalog therapy for nephrotic patients: results from a single-center pilot study. Int J Nephrol Renovasc Dis 8:7-12

132. Wang CS, Travers C, McCracken C, Leong T, Gbadegesin R, Quiroga A, Benfield MR, Hidalgo G, Srivastava T, Lo M, Yadin O, Mathias R, Araya CE, Khalid M, Orjuela A, Zaritsky J, AlAkash S, Kamel M, Greenbaum LA (2018) Adrenocorticotropic hormone for childhood nephrotic syndrome: the ATLANTIS randomized trial. Clin J Am Soc Nephrol 13:1859-1865

133. Hartung DM, Johnston K, Deodhar A, Bourdette DN, Cohen DM (2019) Repository corticotropin versus glucocorticoid for nephrotic syndrome: when will we see the evidence? Am J Kidney Dis 74: 256-262

134. Hartung DM, Johnston K, Cohen DM, Nguyen T, Deodhar A, Bourdette DN (2018) Industry payments to physician specialists who prescribe repository corticotropin. JAMA Netw Open 1: e180482

135. Hartung DM, Johnston K, Van Leuven S, Deodhar A, Cohen DM, Bourdette DN (2017) Trends and characteristics of US Medicare spending on repository corticotropin. JAMA Intern Med 177: 1680-1682

136. Zhang X, Peng Y, Fan Z, Zhao K, Chen X, Lin R, Sun J, Wang G, Xiang A, Liu Q (2017) Mesenchymal stem cells may ameliorate nephrotic syndrome post-allogeneic hematopoietic stem cell transplantation-case report. Front Immunol 8:962

137. Belingheri M, Lazzari L, Parazzi V, Groppali E, Biagi E, Gaipa G, Giordano R, Rastaldi MP, Croci D, Biondi A, Rebulla P, Edefonti A, Ghio L (2013) Allogeneic mesenchymal stem cell infusion for the stabilization of focal segmental glomerulosclerosis. Biologicals 41:439-445

138. Mallipattu SK, He JC (2015) The beneficial role of retinoids in glomerular disease. Front Med (Lausanne) 2:16

139. Harita Y (2018) Application of next-generation sequencing technology to diagnosis and treatment of focal segmental glomerulosclerosis. Clin Exp Nephrol 22:491-500

140. Hinkes B, Wiggins RC, Gbadegesin R, Vlangos CN, Seelow D, Nurnberg G, Garg P, Verma R, Chaib H, Hoskins BE, Ashraf S, Becker C, Hennies HC, Goyal M, Wharram BL, Schachter AD, Mudumana S, Drummond I, Kerjaschki D, Waldherr R, Dietrich A, Ozaltin F, Bakkaloglu A, Cleper R, Basel-Vanagaite L, Pohl M, Griebel M, Tsygin AN, Soylu A, Muller D, Sorli CS, Bunney TD, Katan M, Liu J, Attanasio M, O'Toole JF, Hasselbacher K, Mucha B, Otto EA, Airik R, Kispert A, Kelley GG, Smrcka AV, Gudermann T, Holzman LB, Nurnberg P, Hildebrandt F (2006) Positional cloning uncovers mutations in PLCE1 responsible for a nephrotic syndrome variant that may be reversible. Nat Genet 38: 1397-1405

141. Malina M, Cinek O, Janda J, Seeman T (2009) Partial remission with cyclosporine a in a patient with nephrotic syndrome due to NPHS2 mutation. Pediatr Nephrol 24:2051-2053

142. Wasilewska AM, Kuroczycka-Saniutycz E, Zoch-Zwierz W (2011) Effect of cyclosporin a on proteinuria in the course of glomerulopathy associated with WT1 mutations. Eur J Pediatr 170:389-391

143. Heeringa SF, Vlangos CN, Chernin G, Hinkes B, Gbadegesin R, Liu J, Hoskins BE, Ozaltin F, Hildebrandt F, Members of the APN Study Group (2008) Thirteen novel NPHS1 mutations in a large cohort of children with congenital nephrotic syndrome. Nephrol Dial Transplant 23:3527-3533

144. Santin S, Ars E, Rossetti S, Salido E, Silva I, Garcia-Maset R, Gimenez I, Ruiz P, Mendizabal S, Luciano Nieto J, Pena A, Camacho JA, Fraga G, Cobo MA, Bernis C, Ortiz A, de Pablos AL, Sanchez-Moreno A, Pintos G, Mirapeix E, Fernandez-Llama P, Ballarin J, Torra R, Group FS, Zamora I, Lopez-Hellin J, Madrid A, Ventura C, Vilalta R, Espinosa L, Garcia C, Melgosa M, Navarro M, Gimenez A, Cots JV, Alexandra S, Caramelo C, Egido J, San Jose MD, de la Cerda F, Sala P, Raspall F, Vila A, Daza AM, Vazquez M, Ecija JL, Espinosa M, Justa ML, Poveda R, Aparicio C, Rosell J, Muley R, Montenegro J, Gonzalez D, Hidalgo E, de Frutos DB, Trillo E, Gracia S, de los Rios FJ (2009) TRPC6 mutational analysis in a large cohort of patients with focal segmental glomerulosclerosis. Nephrol Dial Transplant 24:3089-3096

145. Dorval G, Gribouval O, Martinez-Barquero V, Machuca E, Tete MJ, Baudouin V, Benoit S, Chabchoub I, Champion G, Chauveau D, Chehade H, Chouchane C, Cloarec S, Cochat P, Dahan K, Dantal J, Delmas Y, Deschenes G, Dolhem P, Durand D, Ekinci Z, El Karoui K, Fischbach M, Grunfeld JP, Guigonis V, Hachicha M, Hogan J, Hourmant M, Hummel A, Kamar N, Krummel T, Lacombe D, Llanas B, Mesnard L, Mohsin N, Niaudet P, Nivet H, Parvex P, Pietrement C, de Pontual L, Noble CP, Ribes D, Ronco P, Rondeau E, Sallee M, Tsimaratos M, Ulinski T, Salomon R, Antignac C, Boyer O (2018) Clinical and genetic heterogeneity in familial steroid-sensitive nephrotic syndrome. Pediatr Nephrol 33:473-483

146. Gee HY, Zhang F, Ashraf S, Kohl S, Sadowski CE, Vega-Warner V, Zhou W, Lovric S, Fang H, Nettleton M, Zhu JY, Hoefele J, Weber LT, Podracka L, Boor A, Fehrenbach H, Innis JW, Washburn J, Levy S, Lifton RP, Otto EA, Han Z, Hildebrandt F (2015) KANK deficiency leads to podocyte dysfunction and nephrotic syndrome. J Clin Invest 125:2375-2384

147. Gee HY, Ashraf S, Wan X, Vega-Warner V, Esteve-Rudd J, Lovric S, Fang H, Hurd TW, Sadowski CE, Allen SJ, Otto EA, Korkmaz E, Washburn J, Levy S, Williams DS, Bakkaloglu SA, Zolotnitskaya A, Ozaltin F, Zhou W, Hildebrandt F (2014) Mutations in EMP2 cause childhood-onset nephrotic syndrome. Am J Hum Genet 94:884-890

148. Xing CY, Saleem MA, Coward RJ, Ni L, Witherden IR, Mathieson PW (2006) Direct effects of dexamethasone on human podocytes. Kidney Int 70:1038-1045

149. Faul C, Donnelly M, Merscher-Gomez S, Chang YH, Franz S, Delfgaauw J, Chang JM, Choi HY, Campbell KN, Kim K, Reiser J, Mundel P (2008) The actin cytoskeleton of kidney podocytes is a direct target of the antiproteinuric effect of cyclosporine a. Nat Med 14:931-938

150. Buscher AK, Kranz B, Buscher R, Hildebrandt F, Dworniczak B, Pennekamp P, Kuwertz-Broking E, Wingen AM, John U, Kemper M, Monnens L, Hoyer PF, Weber S, Konrad M (2010) Immunosuppression and renal outcome in congenital and pediatric steroid-resistant nephrotic syndrome. Clin J Am Soc Nephrol 5: 2075-2084

151. Buscher AK, Beck BB, Melk A, Hoefele J, Kranz B, Bamborschke D, Baig S, Lange-Sperandio B, Jungraithmayr T, Weber LT, Kemper MJ, Tonshoff B, Hoyer PF, Konrad M, Weber S, German Pediatric Nephrology Association (GPN) (2016) Rapid response to Cyclosporin a and favorable renal outcome in nongenetic versus genetic steroid-resistant nephrotic syndrome. Clin J Am Soc Nephrol 11:245-253 
152. Desbats MA, Lunardi G, Doimo M, Trevisson E, Salviati L (2015) Genetic bases and clinical manifestations of coenzyme Q10 (CoQ 10) deficiency. J Inherit Metab Dis 38:145-156

153. Gigante M, Diella S, Santangelo L, Trevisson E, Acosta MJ, Amatruda M, Finzi G, Caridi G, Murer L, Accetturo M, Ranieri E, Ghiggeri GM, Giordano M, Grandaliano G, Salviati L, Gesualdo L (2017) Further phenotypic heterogeneity of CoQ10 deficiency associated with steroid resistant nephrotic syndrome and novel COQ2 and COQ6 variants. Clin Genet 92:224-226

154. Diomedi-Camassei F, Di Giandomenico S, Santorelli FM, Caridi G, Piemonte F, Montini G, Ghiggeri GM, Murer L, Barisoni L, Pastore A, Muda AO, Valente ML, Bertini E, Emma F (2007) COQ2 nephropathy: a newly described inherited mitochondriopathy with primary renal involvement. J Am Soc Nephrol 18:2773-2780

155. Heeringa SF, Chernin G, Chaki M, Zhou W, Sloan AJ, Ji Z, Xie LX, Salviati L, Hurd TW, Vega-Warner V, Killen PD, Raphael Y, Ashraf S, Ovunc B, Schoeb DS, McLaughlin HM, Airik R, Vlangos CN, Gbadegesin R, Hinkes B, Saisawat P, Trevisson E, Doimo M, Casarin A, Pertegato V, Giorgi G, Prokisch H, Rotig A, Nurnberg G, Becker C, Wang S, Ozaltin F, Topaloglu R, Bakkaloglu A, Bakkaloglu SA, Muller D, Beissert A, Mir S, Berdeli A, Varpizen S, Zenker M, Matejas V, Santos-Ocana C, Navas P, Kusakabe T, Kispert A, Akman S, Soliman NA, Krick S, Mundel P, Reiser J, Nurnberg P, Clarke CF, Wiggins RC, Faul
C, Hildebrandt F (2011) COQ6 mutations in human patients produce nephrotic syndrome with sensorineural deafness. J Clin Invest 121:2013-2024

156. Ashraf S, Gee HY, Woerner S, Xie LX, Vega-Warner V, Lovric S, Fang H, Song X, Cattran DC, Avila-Casado C, Paterson AD, Nitschke P, Bole-Feysot C, Cochat P, Esteve-Rudd J, Haberberger B, Allen SJ, Zhou W, Airik R, Otto EA, Barua M, Al-Hamed MH, Kari JA, Evans J, Bierzynska A, Saleem MA, Bockenhauer D, Kleta R, El Desoky S, Hacihamdioglu DO, Gok F, Washburn J, Wiggins RC, Choi M, Lifton RP, Levy S, Han Z, Salviati L, Prokisch H, Williams DS, Pollak M, Clarke CF, Pei Y, Antignac C, Hildebrandt F (2013) ADCK4 mutations promote steroid-resistant nephrotic syndrome through CoQ10 biosynthesis disruption. J Clin Invest 123:5179-5189

157. Montini G, Malaventura C, Salviati L (2008) Early coenzyme Q10 supplementation in primary coenzyme Q10 deficiency. N Engl J Med 358:2849-2850

158. Park E, Kang HG, Choi YH, Lee KB, Moon KC, Jeong HJ, Nagata M, Cheong HI (2017) Focal segmental glomerulosclerosis and medullary nephrocalcinosis in children with ADCK4 mutations. Pediatr Nephrol 32:1547-1554

Publisher's note Springer Nature remains neutral with regard to jurisdictional claims in published maps and institutional affiliations. 